\title{
Profesionalitas Seorang Guru Terhadap Motivasi Belajar Siswa
}

\author{
layyinatul khoiriyah \\ Program Studi teknik lingkungan \\ Fakultas teknik \\ Universitas Nahdlatul Ulama Sidoarjo \\ Email: layyinatulkhoiriyah45@gmail.com
}

Pengantar

Background (noun latar belakang. 1. pekerjaan atau pengalaman masa lalu; 2. rincian masa lalu (Purnomo, Putri, and Rosyidah 2017)). Pendidikan adalah suatu kegiatan pembentukan kesadaran dan kepribadian anak didik di samping transfer ilmu dan keahlian(Qori'ah, S., Sholikhah, S.A., Purnomo, A., \& Rosyidah 2017) Masyarakat dari yang paling terbelakang sampai yang paling maju mengakui bahwa pendidikan adalah suatu bentuk investasi jangka panjang yang penting bagi seorang manusia. Pendidikan yang berhasil akan menciptakan manusia yang pantas dan berkelayakan di masyarakat serta tidak menyusahkan orang lain. Masyarakat dari yang paling terbelakang sampai yang paling maju mengakui bahwa pendidikan atau guru merupakan satu diantara sekian banyak unsur pembentuk utama calon anggota utama masyarakat, Pendidkan yang berhasil akan menciptakan manusia yang pantas dan berkelayakan di masyarakat sehingga menjadi penting pendidikan untuk mencetak manusia yang memiliki berkualitas dan berdaya saing(Arianto 2013).

Beberapa guru tersebut melayani kelompok, individu, dan bahkan komunitas yang bebas, terbuka, besar. Mereka mempersonalisasi pengalaman belajar untuk para siswa, mencari nafkah, dan membayarnya ke depan dengan membantu orang lain(Purnomo 2016). Dosen atau gutu sebagai tenaga profesional wajib mewujudkan tujuan pendidikan nasional sesuai pembukaan UUD 1945, yaitu mencerdaskan kehidupan bangsa serta memperoleh hak yang sama sesuai pembukaan UUD 1945, yaitu keadilan sosial dengan prinsip kesetaraan dan kesejawatan sesuai dengan peraturan perundangundangan(Sutiksno 2018). Guru harus bisa membangun generasi muda untuk masa depan. Hiduplah untuk mengamalkan ilmu. Senantiasa belajar dan bekerja keras. Bersabarlah dengan masalah, sesungguhnya didalam kesulitan ada kemudahan (Qori'ah, S., Sholikhah, S.A., Purnomo, A., \& Rosyidah 2017).

Guru merupakan faktor utama dalam proses pendidikan. Meskipun fasilitas pendidikannya lengkap dan cang- gih, namun bila tidak ditunjang oleh keberadaan guru yang berkualitas, mus- tahil akan menimbulkan proses belajar dan pembelajaran yang maksimal (Widoyoko and Rinawati 2012). Proses pembelajaran akan berhasil manakala siswa mempunyai motivasi dalam belajar. Oleh karena itu, guru perlu menumbuhkan motivasi belajar siswa. Untuk 
memperoleh hasil belajar yang optimal,guru dituntut kreatif membangkitkan motivasi belajar sisw (Suprihatin 2015). Hubungan pendidikan antara guru dan murid itu seperti aliran listrik dengan lampu. Bagaimana lampu itu bisa menyala kalau aliran listriknya juga mati . Bagaimana murid itu bisa berprestasi sedangkan guru sendiri tidak pernah berprestasi dan mendoakan. Pendidikan adalah menyampaikan ilmu dan mentransformasi orang lain menjadi lebih baik(Qori'ah, S., Sholikhah, S.A., Purnomo, A., \& Rosyidah 2017). Sekolah sebagai lembaga pendidikan dapat dikategorikan sebagai lembaga industri mulia karena melaksanakan misi yang ganda yaitu profit sekaligus sosial. Misi profit untuk mencapai keuntungan yang dapat dicapai ketika efisiensi dan efektivitas dana bisa tercapai sehingga pemasukan lebih besar dari pada biaya operasional. Sedangkan misi sosialnya bertujuan untuk mewariskan dan menginternalisasikan nilai-nilai luhur (Farahani 2005).

Faktor internal dimaksud adalah menuntut motivasi, kreativitas dan produktivitas guru dalam mengembangkan metode pembelajaran. Sementara faktor eksternal adalah dukungan finansial, sarana-prasarana, kontrol akademik maupun manajemen akademik yang dialokasikan dan dikembangkan oleh sekolah. Dengan ketersediaannya semua fasilitas tersebut sangat dimungkinkan akan terjadinya kemudahan yang dirasakan oleh guru dalam upaya untuk mengembangkan metode pembelajaran. Dengan kata lain, dukungan yang memadai yang diberikan oleh sekolah akan dapat memberikan hasil maksimal terhadap upaya guru dalam mengembangkan metode pembelajaran. Bahwa para guru mayoritas menggunakan metode metode kombinasi, campuran, gabungan atau eklektik. Selain itu, metode yang mereka gunakan yaitu metode ceramah, demonstrasi, diskusi, pemberian tugas, tanya jawab, praktikum, eksperimen, problem solving, dan lain- lain.

Apresiasi guru terhadap penggunaan metode kombinasi yaitu metode yang digunakan harus sesuai dengan pokok bahasan atau materi yang akan disampaikan. Karena itu, metodenya bisa berubah- ubah dan tentu saja harus mengkaitkan dengan suasana kelas, aktivitas siswa, fasilitas dan sarana-prasarana sekolah. Sementara itu, hanya sebagian kecil saja guru yang memakai dua metode yakni ceramah dan tanya jawab (brainstorming). Dalam pandangan mereka bahwa dua metode tersebut adalah sangat efektif dalam menyampaikan semua jenis materi kepada siswa (Zaini 2013).

Guru dalam proses pembelajaran di kelas dipandang dapat memainkan peran penting terutama dalam membantu peserta didik untuk membangun sikap positif dalam belajar, membangkitkan rasa ingin tahu, mendorong kemandirian dan ketepatan logika intelektual, serta menciptakan kondisi- kondisi untuk sukses dalam belajar. Kinerja dan kompetensi guru memikul tanggung jawab utama dalam transformasi orientasi peserta didik dari ketidaktahuan menjadi tahu, dari ketergantungan menjadi mandiri, dari tidak terampil manjadi terampil, dengan 
metode-metode pembelajaran bukan lagi mempersiapkan peserta didik yang pasif, melainkan peserta didik berpengetahuan yang senantiasa mampu menyerap dan menyesuaikan diri dengan informasi baru dengan berpikir, bertanya, menggali, mencipta dan mengembangkan cara-cara tertentu dalam memecahkan masalah yang berkaitan dengan kehidupannya. kompetensi seseorang terbentuk karena adanya dua faktor utama yang mempengaruhi, yakni

(1) faktor internal, yaitu potensi bawaan yang dimiliki seseorang sejak lahir yang diturunkan dari orangtua.

(2) faktor eksternal, yaitu potensi lingkungan yang membentuk seseorang untuk memiliki potensi.

Dengan demikian kompetensi adalah segala sesuatu yang dimiliki oleh seseorang dapat berupa pengetahuan, keterampilan dan sebagainya untuk dapat mengerjakan sesuatu pekerjaan (Muh. Ilyas Ismail 2010). Kreativitas sebagai faktor mental manusia telaah lama diperbincangkan oleh para ahli, namun sampai saat ini penerapannya di sekolah indonesia belum seperti apa yang diharapkan. Dengan melatih pesrta didik untuk berpikir dan menemukan suatu pengetahuan, tanpa di sadari seorang Pendidik termasuk sudah menekankan pada pengembangan berpikir logis dan konvergen (berpikir ke satu arah) seorang siswa tersebut (Ayyubi n.d.).

Kompetensi Sering terjadi siswa yang kurang berprestasi bukan disebabkan oleh kemampuannya yang kurang, akan tetapi dikarenakan tidak adanya motivasi untuk belajar sehingga ia tidak berusaha untuk mengarahkan segala kemampuannya. Dalam proses pembelajaran tradisional yang menggunakan pendekatan ekspositori kadang-kadang unsur motivasi terlupakan oleh guru.

Guru seakan-akan memaksakan siswa menerima materi yang disampaikannya. Keadaan ini tidak menguntungkan karena siswa tidak dapat belajar secara optimal yang tentunya pencapaian hasil belajar juga tidak optimal. Pandangan moderen tentang proses pembelajaran menempatkan motivasi sebagai salah satu aspek penting dalam membangkitkan motivasi belajar siswa. Siswa perlu memahami apa yang diketahui dan apa yang diminta untuk memiliki kemampuan menjawab(Suci, S. H. A., Rosyidah, E., Asitah, N., Aini, N., Murni, A. W., Anam, F., Purnomo, A., Sallu, S., Mulyaningsih, I., \& Kuraesin 2018). Motivasi adalah serangkaian usaha untuk menyediakan kondisi-kondisi tertentu, sehingga seseorang mau dan ingin melakukan sesuatu dan bila tidak suka maka akan berusaha untuk meniadakan atau mengelakkan perasaan tidak suka itu. Jadi motivasi dapat dirangsang oleh faktor dari luar, tetapi motivasi itu tumbuh di dalam diri seseorang. Lingkungan merupakan salah faktor dari luar yang dapat menumbuhkan motivasi dalam diri seseorang untuk belajar. faktor-faktor yang mempengaruhi motivasi belajar antara lain

1. Cita-cita/aspirasi siswa

2. Kemampuan siswa 
3. Kondisi siswa dan lingkungan

4. Unsur-unsur dinamis dalam belajar

5. Upaya guru dalam membelajarkan siswa.

Motivasi mempunyai fungsi yang penting dalam belajar, karena motivasi akan menentukan intensitas usaha belajar yang dilakukan siswa. ada tiga fungsi motivasi, yaitu

1. Mendorong manusia untuk berbuat. Motivasi dalam hal ini merupakan motor penggerak dari setiap kegiatan yang akan dikerjakan.

2. Menuntun arah perbuatan, yakni ke arah tujuan yang hendak dicapai, dengan demikian motivasi dapat memberi arah, dan kegiatan yang harus dikerjakan sesuai dengan rumusan tujuannya.

3. Menyeleksi perbuatan, yakni menentukan perbuatan-perbuatan apa yang harus dikerjakan yang serasi guna mencapai tujuan, dengan menyisihkan perbuatan-perbuatan yang tidak bermanfaat bagi tujuan tersebut(Suprihatin 2015).

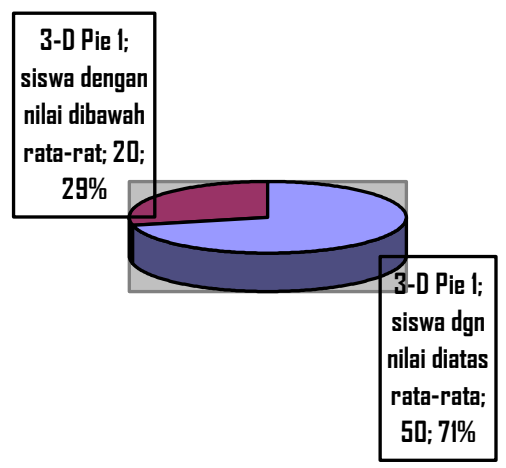

Grafik peningkatan motivasi belajar para siswa di era milinial dengan bantuan guru yang mulai memahami metode-metode terbaru

kesimpulan

Motivasi dapat diartikan sebagai kekuatan seseorang yang dapat menimbulkan tingkat kemauan dalam melaksanakan suatu kegiatan. Kemauan baik yang bersumber dari dalam diri individu itu sendiri (motivasi intrinsik) maupun dari luar individu (motivasi ekstrinsik). Seberapa kuat motivasi yang dimiliki individu akan banyak menentukan kualitas perilaku yang ditampilkannya, baik dalam konteks belajar, bekerja maupun dalam kehidupan lainnya. 
Daftar pustaka

Arianto, dwi agung nugroho. 2013. "PENGARUH KEDISIPLINAN, LINGKUNGAN KERJA DAN BUDAYA KERJA TERHADAP KINERJA TENAGA PENGAJAR Dwi Agung Nugroho Arianto.” Economia 9(2): 191200.

Ayyubi, Ahmad fahmi. "KREATIVITAS DAN KOMPETENSI GURU

SEKOLAH DASAR Ahmad Fahmi Ayyubi." : 1-6.

Farahani, Erly. 2005. "MENUMBUH KEMBANGKAN BUDAYA KEWIRAUSAHAAN DALAM MASYARAKAT."

Muh. Ilyas Ismail. 2010. "Ismail, KINERJA DAN KOMPETENSI GURU DALAM PEMBELAJARAN Oleh: Muh. Ilyas Ismail * ABSTRAK:" Kinerja Dan Kompetensi Guru Dalam Pembelajaran 13(1): 44-63.

Purnomo, Agung. 2016. "Pengertian Edupreneur." : 3-4.

Purnomo, Agung, Rizki Amalia Putri, and Elsa Rosyidah. 2017. "Kamus Manajemen Sumber Daya Manusia."

Qori'ah, S., Sholikhah, S.A., Purnomo, A., \& Rosyidah, E. 2017. "Wirausaha Pendidikan Indonesia Jilid 3."

Suci, S. H. A., Rosyidah, E., Asitah, N., Aini, N., Murni, A. W., Anam, F., Purnomo, A., Sallu, S., Mulyaningsih, I., \& Kuraesin, A. D. 2018. "Learning from Picture and Picture Action Research : Enhancement of Counting Ability on Division of Numbers for Primary School Students."

Suprihatin, Siti. 2015. "Motivasi Mempunyai Fungsi Yang Penting Dalam Belajar. Ada Tiga Fungsi Motivasi, Sebagai Berikut: 1. Mendorong Manusia Untuk Berbuat. Motivasi Dalam Hal Ini Merupakan Motor Penggerak Dari Setiapkegiatan Yang Akan Dikerjakan. 2. Menuntun Arah Perbuatan, Yak." 3(1): 73-82.

Sutiksno, Dr.dian utami. 2018. “A. Profil Idri.” (September 2015): 1-73.

Widoyoko, S. Eko Putro, and Anita Rinawati. 2012. "Pengaruh Kinerja Guru Terhadap Motivasi Belajar Siswa.” Jurnal Cakrawala Pendidikan 2(2): 27889.

Zaini, Ahmad Afan H. 2013. "Upaya Guru Dalam Mengembangkan Metode Pembelajaran.” Jurnal Ummul Qura III(2): 40-48. 